\title{
Palaeomagnetism of Late Miocene to Quaternary volcanics from the eastern segment of the Trans-Mexican Volcanic Belt
}

\author{
V.C. Ruiz-Martínez ${ }^{\text {a, }}$, , M.L. Osete ${ }^{\text {a }}$, R. Vegas ${ }^{\text {b }}$, J.I. Núñez-Aguilar ${ }^{\text {a }}$, \\ J. Urrutia-Fucugauchi ${ }^{\mathrm{c}}$, D.H. Tarling ${ }^{\mathrm{d}}$ \\ ${ }^{\text {a }}$ Dep. Geofísica, F.CC. Físicas, Complutense University, Madrid 28040, Spain \\ ${ }^{\mathrm{b}}$ Dep. Geodinámica, F. C.C. Geológicas, Complutense University, Madrid 28040, Spain \\ ${ }^{\mathrm{c}}$ Instituto de Geofísica, Univ. Nacional Autónoma de México, 04510 México DF, México \\ ${ }^{\mathrm{d}}$ Dep. Geological Sciences, Plymouth University, Drake Circus, Plymouth PL4 8AA, UK
}

\begin{abstract}
A systematic palaeomagnetic study in the eastern part of the Trans-Mexican Volcanic Belt includes 39 Miocene, Pliocene and Quaternary volcanic rocks in the southeastern Mexico Basin (Sierra Nevada and Sierra de Río Frío), the Altiplano area, and the Palma Sola Massif. A total of 430 samples have been selectively demagnetized using mostly alternating field demagnetizing methods, supplemented by thermal analyses. Most characteristic remanences are carried by low-Ti titanomagnetites, with occasional titanohematites or slightly maghemitized low-Ti titanomagnetites, of similar direction. Seven sites were discarded because they presented intermediate directions, hydrothermal alteration or were remagnetized by lightning strikes. The mean directions of 32 sites, together with 24 sites from Sierra de las Cruces in the western Mexico basin, indicate rocks older than $2 \mathrm{Ma}$ are rotated some $10^{\circ}$ counterclockwise with respect to Quaternary rocks, whereas there is no rotational difference between Miocene and Pliocene rocks. Statistical analyses between different regrouped populations confirm that the rotational pattern is due to the age of the volcanics rocks but not to their spatial distribution. The Quaternary mean direction from the three Mexico Basin ranges is consistent with the geographical reference pole. In contrast, the Pliocene mean direction from volcanic rocks of the Altiplano area and the Sierra de Las Cruces is slightly rotated some $10^{\circ}$ westwards with respect to the reference direction from North America. No significant rotations have been observed in the eastern TMVB (from the western Mexico Basin to the border of the Altiplano), between late Miocene and late Pliocene times. It suggests that a very small, counterclockwise vertical-axis rotation may have been taken place in this segment of the TMVB between late Pliocene and Quaternary times. Comparisons of these results with a summary of the available palaeomagnetic data in the area indicate that the previously reported Quaternary rotations are of questionable reliability, and that the large counterclockwise rotations, reported in Cretaceous to Miocene rocks, probably took place before the late Miocene. These new palaeomagnetic data support the idea that the eastern TMVB since the late Miocene, has been a zone of extension with a little, left-lateral shear component.
\end{abstract}

Keywords: block rotations; palaeomagnetism; tectonics; Trans-Mexican Volcanic Belt.; volcanism

* Corresponding author. Fax: +34-1394-4398.

E-mail address: vcarlos@eucmax.sim.ucm.es (V.C. Ruiz-Martínez) 


\section{Introduction}

The Trans-Mexican Volcanic Belt (TMVB) is a high-altitude volcanic province that traverses central Mexico from the Pacific Ocean to the Gulf of Mexico. It is currently associated with subduction of the Cocos and Rivera plates along the Middle America trench, but has some unusual features that have remained controversial in spatial-temporal evolutionary models, of which three are considered here:

(1) the chemistry and distribution of volcanic rocks along the arc (alkaline products in both extremes of the calcalkaline arc, lamprophyres on the western volcanic front) are anomalous (e.g. Cantagrel and Robin, 1979; Luhr and Carmichael, 1985; Lange and Carmichael, 1991);

(2) the trend of the magmatic arc is some $15-$ $20^{\circ}$ oblique to the trench; and

(3) the migration of the volcanism is southerly (e.g. Delgado-Granados et al., 1995; Osete et al., 2000) rather than perpendicular to the direction of subduction.

These special characteristics have given rise to contrasting models to explain the tectonic origin and subsequent development of the TMVB. Extensive geophysical studies are being conducted to define the geometry of the subducted slab of oceanic lithosphere beneath the southern Mexican continental margin (e.g. Bandy et al., 1995; Pardo and Suárez, 1995, Dañobeitia et al., 1997). The magmatic arc is mostly related to this active subduction (e.g. Molnar and Sykes, 1969; UrrutiaFucugauchi and Del Castillo, 1977; Nixon, 1982; Burbach et al., 1984; Suárez and Singh, 1986). Models invoke different plate geometries and kinematics to account for the characteristics of the TMVB, including fragmentation and/or bending of the subducted plate, influence of the crustal structure of the overriding plate and control of the magmatic activity by fractures and zones of crustal weakness. However, non-subduction models have also been proposed, explaining the origin of the TMVB as resulting from zones of weakness within the crust, inherited from earlier episodes of deformation (e.g. Mooser, 1972; Johnson and Harrison, 1989 ). The arc is also not genetically related with the subduction but associated with the northern boundary of a microplate subjected to clockwise rotation as result of a lithospheric transtension (Shurbet and Cebull, 1984). Strike-slip megashear models have been suggested by several authors (e.g. De Cserna, 1970, 1976; Urrutia-Fucugauchi, 1981, 1983, 1984; Anderson and Schmidt, 1983; Böhnel, 1985). The age, sense and amount of lateral displacement vary from model to model, but a secondary plate-boundary is invoked in which some California-type, large, vertical-axis block rotations could be expected. In contrast, if the location of the TMVB is a zone of extension along a diffuse zone of weakness, then no substantial vertical-axis block rotations should be conspicuous.

Tectonically, the TMVB can be divided into three segments (Fig. 1). Post-Pliocene rifting, resulting in the Tepic-Chapala, Chapala and Colima rifts, which merge in a rift-rift-rift triple junction, characterizes the western segment. The central segment is characterized by E-W-striking normal faults and small grabens (Cuitzeo, Acambay, etc.), which have been active in recent times (e.g. Johnson and Harrison, 1990). The third segment is to the east of the Queretaro-Taxco lineament (Pasquaré et al., 1991), of which the TMVB forms the eastern sector, where small NWSE-trending basins and ridges delineate a zone with widespread volcanism but without any clear, large E-W lineaments. In addition to the TMVB, the Eastern Alkaline Province (EAP), of Oligocene also represents recent volcanism in eastern Mexico to Quaternary age (Demant and Robin, 1975).

These kinds of volcanic rocks are known, from extensive rock magnetic experiments, to be excellent recorders of magnetic field direction, with titanomagnetite and titanohematites as typically magnetic carriers. This is a thermal remanence acquired soon after eruption, generally quite stable.

Palaeomagnetic studies carried out in the TMVB have suggested the occurrence of block rotations in certain areas of central and eastern Mexico (see summary of Soler-Arechalde et al., 2000). These rotations have been related to a variety of mechanisms, including oblique subduction, regional left-lateral shear, pull-apart basin deformation, lateral fault stepovers, and other 


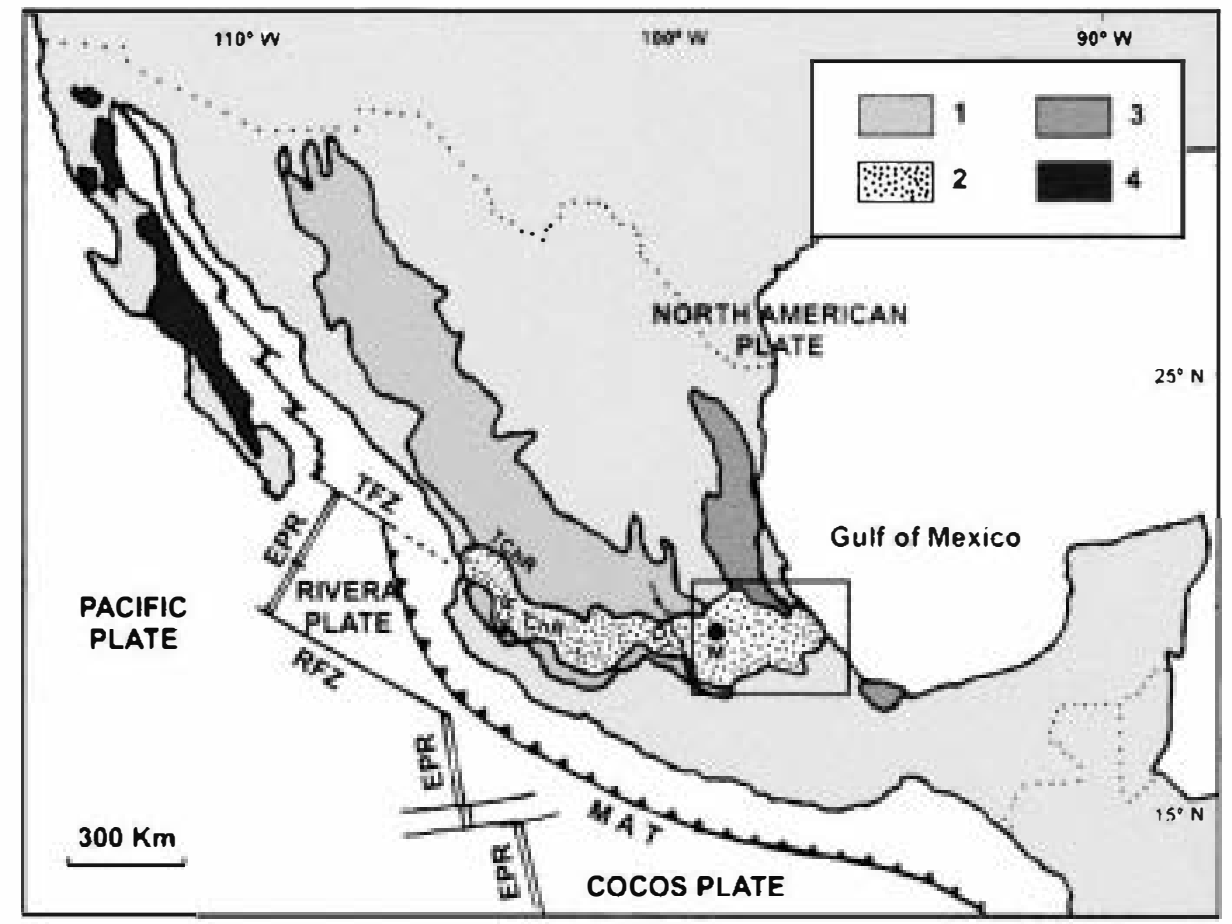

Fig. 1. Geographical location of the study area (rectangle, see Fig. 2). M, Mexico D.F. Mexican volcanic provinces and plate boundaries are those of Demant and Robin (1975) and Drumond (1981), respectively: 1, Sierra Madre Oecidenta 1; 2, Trans-Mexican Vo lcanic Belt (TMVB); 3, Eastern Alkaline Province; 4, Baja Californian Province. MAT, Midd le American Trench; EPR, East Pacific Rise; TFZ, Tamayo Fracture Zone; RFZ, Rivera Fracture Zone. Major structures used to separate the TMVB tectonically into three segmentsare: TChR, Tepic-Chapala Rift; CR, Colima Rift; ChR, Chapala Rift; and QT, Queretaro-Taxco Fault Zone.

mechanisms for local deformation. Consequently, any geodynamic model proposed to explain the origin and evolution of the TMVB must consider the rotational-deformational history of the magmatic arc. In this context, palaeomagnetism is a powerful tool for measuring such tectonic rotations.

Previous palaeomagnetic data from the TMVB (Table 1) show significant divergences of the observed declination from the expected declination, with negative rotation parameters (Beck, 1980) ranging from $R=-15^{\circ}$ to $R=-56^{\circ}$ in some regions of the arc. These results have been interpreted as being due to counterclockwise rotations of the studied areas. However, other regions do not seem to have experienced significant rotations.

Results from the eastern sector of the TMVB (e.g. summary in Urrutia-Fucugauchi and Böhnel, 1988 ) include six sites of different lithologies rang- ing in age from Quaternary to middle Cretaceous with significant negative $R$ parameters (Table 1 ). Results from Quaternary lavas from the Valle de Oriental area ('E1' in Fig. 2 and Table 1) were reported by Böhnel (1985) who considered that most of them were erupted during the upper Brunhes and showed anomalous high anticlockwise rotations $\left(R=-15 \pm 6^{\circ}\right)$. In contrast, Böhnel and Negendank (1981) reported no rotations in a previous palaeomagnetic study carried out in the same eastern region. The Tertiary sites $\left({ }^{6} \mathrm{E} 3, \mathrm{~B}, \mathrm{~J}\right.$, G' in Fig. 2 and Table 1; Böhnel, 1985; UrrutiaFucugauchi, 1980, 1981, 1983) showed anticlockwise rotations ranging from 19 to $56^{\circ}$. The Cretaceous site near Perote ('E2' in Fig. 2 and Table 1; Böhnel, 1985) showed anticlockwise rotations of ca. $40^{\circ}$, but with high scatter. No stability tests were performed in these studies. In addition, the rocks lack good age control. 
Table 1

Summary of previous TMVB palaeopo les (from west to east)

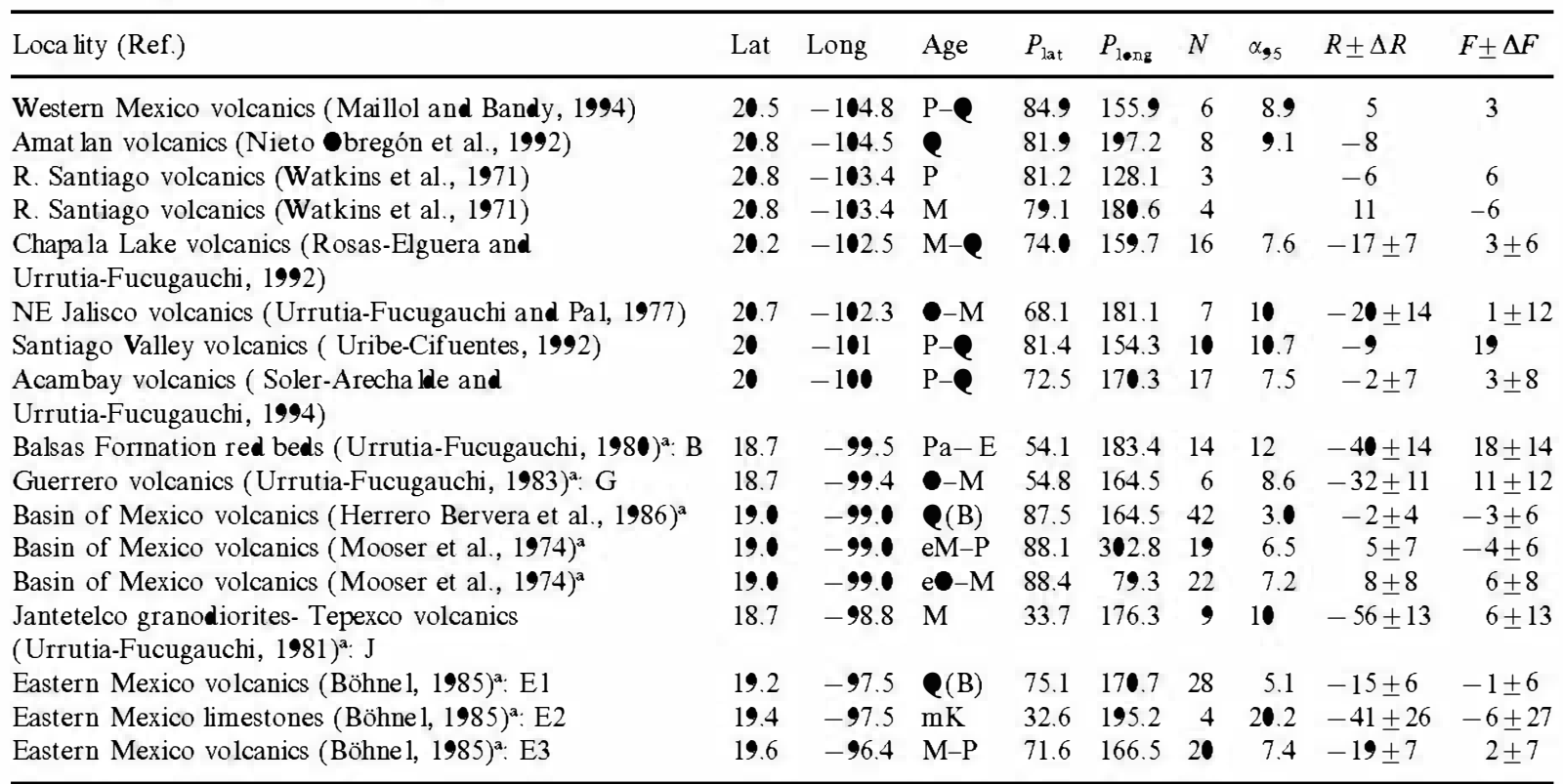

Lat/Long, rock site coordinates; $P_{\text {lat }} / P_{\text {leng }}$, palaeomagnetic pole coordinates; $N$, number of sites; $\alpha, 95 \%$ cone of confidence for Fischer statistics; $R \pm \Delta R / F \pm \Delta F$, rotation/flattening parameters and $95 \%$ statistical uncertainty. Ages: Q, Quaternary (B, Brunhes chron); P, Pliocene; M, Miocene (e, ear ly); - ligocene (e, ear ly); E, Eoœne; Pa, Palaeocene; mK, mid-Cretaceous.

${ }^{a}$ Eastern TMVB sites (B, G, J, E1-3, see Fig. 2).

In view of the importance of these contrasting observations to any understanding of the tectonic setting, size and structural complexity of the arc, one of our main objectives was to document the occurrence, or absence, of such vertical axis rotations as a mechanism of tectonic deformation. Several selected areas across the eastern segment of the TMVB were studied.

\section{Geological setting}

In eastern Mexico, a NNW-striking fault zone separates the Altiplano area at an elevation of some $\mathbf{2 0 0 0} \mathrm{m}$, from the coastal plains along the Gulf of Mexico (Fig. 2). Two magmatic provinces can also be distinguished, the E-W-trending TMVB of mainly Miocene to Quaternary calcalkaline associations, and the EAP, where the late Oligocene to the Quaternary volcanism parallels the eastern coast (Robin, 1976; Demant 1978). The Palma Sola area is located in the coastal plain at the crossing of these two provinces (Figs. 1 and 2) and has a mainly alkaline character but also includes products with calc-alkaline affinities. Alkaline basaltic lavas also occur in the fault zone of the Altiplano border.

According to volcanological and radiometric investigations, the regional-temporal variations of the volcanism of the Altiplano border and the EAP are modeled as a succession of periods of southward migrating, but not contemporaneous, alkaline and andesitic phases in the East. However both provinces crossed each other between 9 and $6 \mathrm{Ma}$ (Cantagrel and Robin, 1979; Robin, 1981). The andesitic zone has undergone three periods of volcanic activity since the Early Miocene: the first one between 30 and $15 \mathrm{Ma}$, the second between 9 and $6 \mathrm{Ma}$, and the last from $3 \mathrm{Ma}$ to the present. There is no consensus about the explanation for the observed volcanism. This crossed-magmatic area is not included as part of the TMVB, and it is postulated as an alkaline-graben-province of intraplate character (Robin, 1981). In contrast 


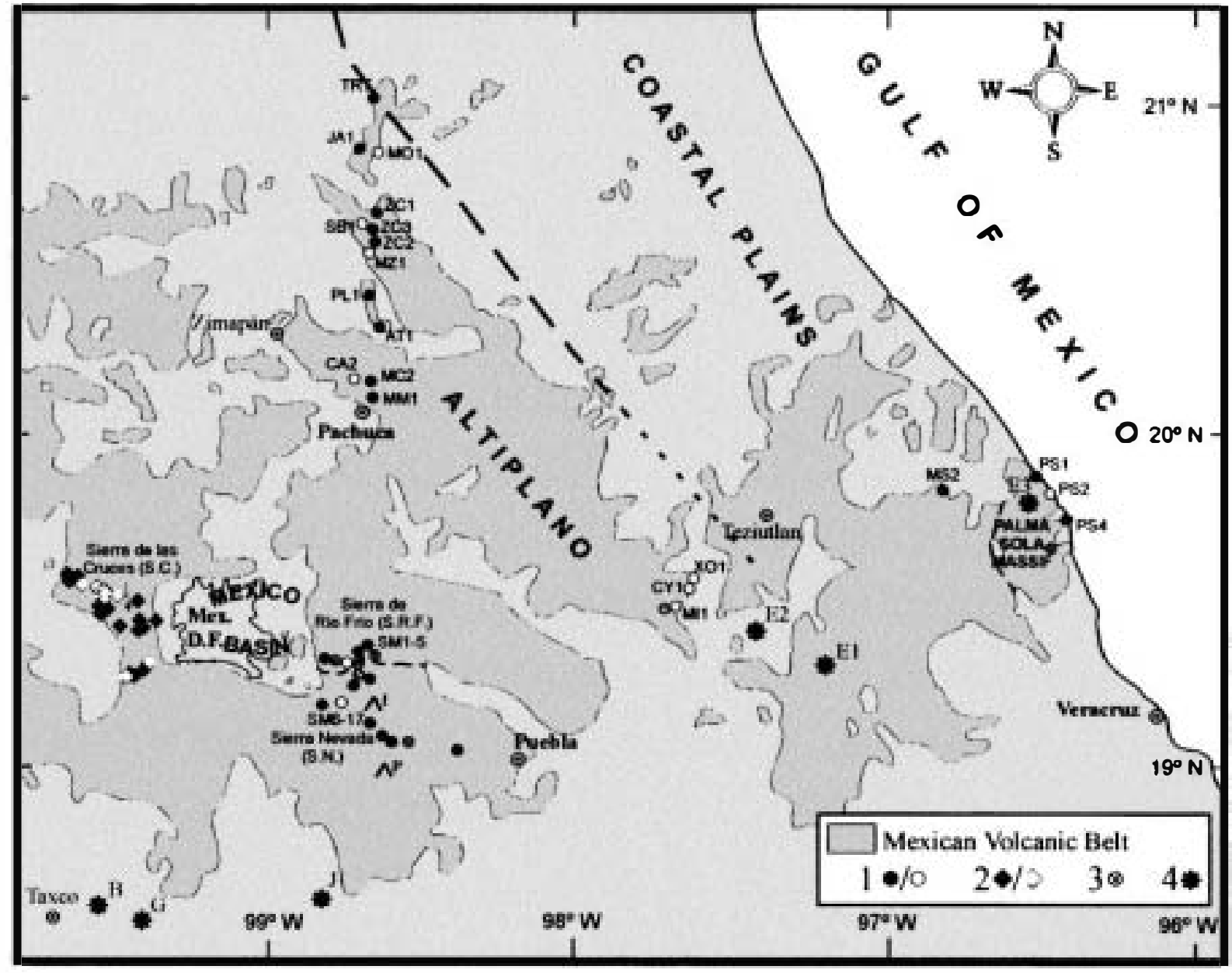

Fig. 2. Simplified map of the eastern TMVB (from Carta geológica de la República Mexicana, 1992) showing the palaeomagnetically investigated sites (open/closed symbols mean reversed/nonnal polarity). 1, This study; 2, Osete et al. (2000); 3, rejected sites; 4, previous palaeomagnetic studies (see Table 1).

and according to geochemical results, the TMVB is argued to contain calc-alkaline, subalkaline and alkaline products, associated with the subduction, and the TMVB Pliocene-Quaternary volcanic activity to end at the Gulf coast rather than in the Altiplano area (Negendank et al., 1985).

The Mexico Basin is taken as the westernmost area of the eastern segment of the TMVB (Fig. 2). The limits of the basin are the Sierras Tezontaplan and Pachuca, to the north and the Quaternary volcanics of the Chichinautzin group to the south. On the west is the Sierra de Las Cruces, considered Miocene by Mooser et al. (1974) and recently dated late Pliocene (Mora-Alvarez et al., 1991; Osete et al., 2000), whereas the eastern border is formed by the Sierra Nevada and the Sierra de Río Frío. Volcanic activity in this region probably began 1.7 Ma ago (Nixon et al., 1987). The Sierra Nevada includes the Iztaccihuatl and Popocatépetl volcanoes (Fig. 2), the latter, at the southern border of the range, being a historically active volcano. The substructures of these volcanoes are composed of relatively large volumes of twopyroxene andesites overlain by more viscous dacitic lavas of the modern cones. Nixon (1989) describes the volcanic evolution of Iztaccihuatl 
Table 2

Summary of palaeomagnetic results

\begin{tabular}{|c|c|c|c|c|c|c|c|c|}
\hline \multicolumn{9}{|c|}{ Sierra de las Cruces (Osete et al., 2000 - this volume) } \\
\hline JQ1 & $\mathrm{P}$ & $19^{\bullet} 34.16^{\prime}$ & $-99^{\bullet} 35.47^{\prime}$ & $10 / 10$ & 350.4 & 43.1 & 113.0 & 4.6 \\
\hline JQ2 & $371 \pm 40^{d}$ & $19^{\circ} 33.80^{\prime}$ & $-99^{\circ} 34.83^{\prime}$ & $10 / 10$ & 336.4 & 44.1 & 209.9 & 3.3 \\
\hline JQ3 & $\mathrm{P}$ & $19^{\circ} 33.80^{\prime}$ & $-99^{\circ} 34.67^{\prime}$ & $10 / 10$ & 360.7 & 48.3 & 116.9 & 4.5 \\
\hline JQ4 & $\mathrm{P}$ & $19^{\bullet} 33.53^{\prime}$ & $-99^{\circ} 33.63^{\prime}$ & $10 / 10$ & 169.0 & -14.2 & (G.C.A. $\mathrm{mad}=7.3$ ) & \\
\hline IT & $\mathrm{P}$ & $19^{\circ} 31.33^{\prime}$ & $-99^{\circ} 28.50^{\prime}$ & $10 / 10$ & 171.3 & -20.9 & 258.2 & 3.0 \\
\hline IT2 & $\mathrm{P}$ & $19^{\circ} 31.33^{\prime}$ & $-99^{\circ} 28.50^{\prime}$ & $10 / 10$ & 151.3 & -23.0 & 149.0 & 4.0 \\
\hline JI 1 & $\mathrm{P}$ & $19^{\circ} 30.82^{\prime}$ & $-99^{\circ} 28.53^{\prime}$ & $7 / 10$ & 176.5 & -22.3 & 312.2 & 3.4 \\
\hline ST3 & $\mathrm{P}$ & $19^{\circ} 30.00^{\prime}$ & $-99^{\circ} 28.57^{\prime}$ & $10 / 10$ & 174.6 & -33.8 & 211.4 & 3.3 \\
\hline PL & $\mathrm{P}$ & $19^{\circ} 31.30^{\prime}$ & $-99^{\circ} 26.20^{\prime}$ & $10 / 10$ & 12.3 & 23.5 & 225.6 & 3.2 \\
\hline $\mathrm{CH} 1$ & $3045 \pm 25^{d}$ & $19^{\circ} 26.25^{\prime}$ & $-99^{\circ} 19.33^{\prime}$ & $10 / 10$ & 358.5 & 27.1 & 410.3 & 2.4 \\
\hline $\mathrm{CH} 2$ & $\mathrm{P}$ & $19^{\circ} 25.50^{\prime}$ & $-99^{\circ} 20.48^{\prime}$ & $10 / 10$ & 355.2 & 32.2 & 51.6 & 6.8 \\
\hline $\mathrm{CH} 3$ & $\mathrm{P}$ & $19^{\bullet} 26.25^{\prime}$ & $-99^{\circ} 21.30^{\prime}$ & $10 / 10$ & 358.2 & 19.3 & 39.5 & 7.8 \\
\hline GU3 & $\mathrm{P}$ & $19^{\circ} 25.33^{\prime}$ & $-9921.83^{\prime}$ & $10 / 10$ & 357.2 & 36.2 & 115.3 & 4.5 \\
\hline $\mathrm{PC} 2$ & $\mathrm{P}$ & $19^{\circ} 25.33^{\prime}$ & $-99^{\circ} 25.88^{\prime}$ & $10 / 10$ & 358.2 & 26.4 & 197.5 & 3.4 \\
\hline $\mathrm{T} 1$ & Q (M) & $19^{\circ} 17.75^{\prime}$ & $-99^{\circ} 23.95^{\prime}$ & $10 / 10$ & 167.3 & -26.7 & 130.5 & 4.2 \\
\hline $\mathrm{T} 3$ & Q (M) & $19^{\circ} 19.00^{\prime}$ & $-99^{\circ} 19.52^{\prime}$ & $10 / 10$ & 177.0 & -53.9 & 80.1 & 5.4 \\
\hline $\mathrm{T} 2$ & $679 \pm 28^{\mathrm{d}}$ & $19^{\circ} 17.67^{\prime}$ & $-99 \cdot 20.45^{\prime}$ & $9 / 10$ & 362.2 & 32.2 & 170.4 & 4.0 \\
\hline $\mathrm{TO} 4$ & Q (B) & $19^{\circ} 18.42^{\prime}$ & $-999^{\circ} .67^{\prime}$ & $8 / 10$ & 352.1 & 45.6 & 337.7 & 3.0 \\
\hline \multicolumn{9}{|c|}{ Sierra de Ri॰ Fri॰ (this study) } \\
\hline SM 1 & e & $19^{\circ} 19.90^{\prime}$ & $-98^{\bullet} 4700^{\prime}$ & $10 / 10$ & 358.3 & 33.8 & 108.8 & 4.7 \\
\hline SM8 & Q (B) & $19^{\circ} 16.83^{\prime}$ & $-98^{\bullet} 43.22^{\prime}$ & $10 / 10$ & 6.2 & 34.6 & 84.4 & 5.3 \\
\hline$S M 9^{a}$ & $2(B)$ & $19^{\circ} 18.12^{\prime}$ & $-98^{\circ} 42.15^{\prime}$ & $12 / 12$ & 35.3 & -50.1 & 20.0 & 5.7 \\
\hline$S M 10^{\mathrm{a}}$ & 2 & $19^{\circ} 20.50^{\prime}$ & $-98^{\circ} 40.15^{\prime}$ & $12 / 12$ & 37.0 & 0.8 & 7.1 & 17.5 \\
\hline SM11 & Q & $19^{\circ} 03.55^{\prime}$ & $-98^{\bullet} 22.50^{\prime}$ & $10 / 10$ & 5.8 & 16.7 & 48.4 & 7.0 \\
\hline$S M 12^{a}$ & 2 & $19^{\circ} 05.10^{\prime}$ & $-98^{\circ} 31.67^{\prime}$ & $7 / 7$ & 11.6 & 25.7 & 2.7 & 46.2 \\
\hline SM13 & Q (B) & $19^{\circ} 05.17^{\prime}$ & $-98^{\bullet} 35.35^{\prime}$ & $13 / 13$ & 2.1 & 32.9 & 116.0 & 3.9 \\
\hline SM14 & Q (B) & $19^{\circ} 05.57^{\prime}$ & $-98^{\bullet} 37.15^{\prime}$ & $9 / 10$ & 0.9 & 19.7 & 117.5 & 3.9 \\
\hline \multicolumn{9}{|c|}{ Sierra Nevada (this study) } \\
\hline SM15 & Q (B) & $19^{\circ} 08.15^{\prime}$ & $-98^{\bullet} 38.93^{\prime}$ & $11 / 11$ & 4.4 & 32.4 & 84.1 & 5.0 \\
\hline SM16 & Q (M) & $19^{\circ} 12.63^{\prime}$ & $-98^{\circ} 44.43^{\prime}$ & $11 / 11$ & 180.8 & -16.5 & 357.2 & 2.4 \\
\hline SM17 & Q & $19^{\circ} 11.68^{\prime}$ & $-98^{\bullet} 47.78^{\prime}$ & $11 / 11$ & 355.2 & 24.4 & 98.6 & 4.6 \\
\hline \multicolumn{9}{|c|}{ Palma Sola Massif (this study) } \\
\hline PS2 (VE34) & $17.0 \pm 6^{6}$ & $19^{\circ} 43.8^{\prime}$ & $-96^{\bullet} 25.4^{\prime}$ & $12 / 12$ & 167.1 & -45.8 & $($ G.C.A. $\mathrm{mad}=4.5)$ & \\
\hline$P S 3^{\mathbf{b}}(\text { VE71b })^{\mathbf{b}}$ & $14.0 \pm .5^{\circ}$ & $19^{\circ} 37.5^{\prime}$ & $-96^{\bullet} 27.2^{\prime}$ & $10 / 10$ & 234.8 & -55.5 & 41.6 & 7.5 \\
\hline PS4 (VE15) & $\begin{array}{l}6.5 \pm 0.2^{b} \\
(7.2 \pm .2)^{c}\end{array}$ & $19^{\circ} 40.5^{\prime}$ & $-96^{\bullet} 23.6^{\prime}$ & $11 / 11$ & 354.4 & 40.6 & 246.2 & 2.9 \\
\hline
\end{tabular}




\begin{tabular}{|c|c|c|c|c|c|c|c|c|}
\hline Site & Age & Lat & Long & $n / N$ & Dec & Inc & $k$ & $\alpha_{95}$ \\
\hline PS1 (VE1 08) & $31 \pm 1$ & $19^{\circ} 45.4^{\prime}$ & $-96^{\bullet} 25.1^{\prime}$ & $10 / 10$ & 354.4 & 21.1 & 103.3 & 4.8 \\
\hline \multirow[t]{2}{*}{$\mathrm{CA} 2$} & \multirow[t]{2}{*}{ (G.C.) } & \multirow[t]{2}{*}{$20^{\circ} 12.5^{\prime}$} & \multirow{2}{*}{$-98^{\bullet} 450^{\prime}$} & $9 / 11$ & 168.5 & -27.4 & 240.7 & \multirow[t]{2}{*}{3.3} \\
\hline & & & & $11 / 11$ & 167.4 & -27.9 & (G.C.A. mad $=3.3$ ) & \\
\hline MC2 & (G.C.) & $20^{\circ} 120^{\prime}$ & $-98^{\bullet} 43.7^{\prime}$ & $12 / 12$ & 358.1 & 40.3 & 131.8 & 3.8 \\
\hline $\mathrm{XO} 1(\mathrm{VE} 118)^{b}$ & $770.30^{\circ}$ & $19^{\bullet} 37.4^{\prime}$ & $-97^{\bullet} 36.6^{\prime}$ & $12 / 12$ & 153.3 & -51.3 & $(G . C . A . \operatorname{mad}=6.6)$ & 2.8 \\
\hline CY1 (VE118) & $770 \pm .30^{\circ}$ & $19^{\bullet} 37.3^{\prime}$ & $-97^{\bullet} 37.1^{\prime}$ & $11 / 11$ & 200.1 & -56.2 & 559.4 & \multirow[t]{2}{*}{1.9} \\
\hline \multirow[t]{2}{*}{ MI1 (VE118) } & \multirow[t]{2}{*}{$770.30^{\circ}$} & \multirow[t]{2}{*}{$19^{\bullet} 31.5^{\prime}$} & \multirow[t]{2}{*}{$-97^{\bullet} 38.6^{\prime}$} & $11 / 11$ & 157.8 & -24.2 & $($ G.C.A. $\mathrm{mad}=4.2)$ & \\
\hline & & & & $5 / 11$ & 151.6 & -17.8 & 170.5 & 5.9 \\
\hline$M R I^{\text {a }}(\mathrm{VE} 118)^{\mathbf{b}}$ & $7.70 \pm .30^{\circ}$ & $19^{\bullet} 31.4^{\prime}$ & $-97^{\bullet} 39.1^{\prime}$ & $11 / 11$ & 247.8 & -31.6 & (G.C.A. $\operatorname{mad}=2.0)$ & \\
\hline & $5.15 \pm .25^{b}$ & $2041.8^{\prime}$ & $-98^{\bullet} 31.4^{\prime}$ & $10 / 10$ & 147.1 & -47.9 & (G.C.A. mad $=13.3)$ & 4.4 \\
\hline ZC1 (PH141) & $4.40 \pm 10^{\circ}$ & $20^{\bullet} 39.6^{\prime}$ & $-98^{\bullet} 37.2^{\prime}$ & $11 / 11$ & 344.5 & 25.1 & 102.8 & 4.5 \\
\hline MS2-3 (VE94) & $4.2 \pm .10^{b}$ & $19^{\circ} 51.3^{\prime}$ & $-96^{\bullet} 48.9^{\prime}$ & $15 / 15$ & 351.8 & 32.9 & 65.3 & 4.8 \\
\hline $\mathbf{Z C 2}$ & $2.6-4.5($ G.C. $)$ & $20^{\circ} 39.8^{\prime}$ & $-98^{\bullet} 330^{\prime}$ & $10 / 10$ & 359.3 & 34 & 745.7 & 1.8 \\
\hline SB 1 & 2-3 (G.C.) & $20^{\circ} 350^{\prime}$ & $-98^{\bullet} 41.4^{\prime}$ & $13 / 13$ & 168.3 & -30.4 & 229.3 & 2.7 \\
\hline ZC3 & 2-3 (G.C.) & $20^{\bullet} 33.4^{\prime}$ & $-98^{\bullet} 38.8^{\prime}$ & $9 / 10$ & 353.4 & 32.6 & 27.5 & 10 \\
\hline PL 1 (PH62) & $256 \pm 08^{b}$ & $20^{\bullet} 27.7^{\prime}$ & $-98^{\bullet} 40.4^{\prime}$ & $11 / 11$ & 352.5 & 32.6 & 402.9 & 2.3 \\
\hline AT1 (PH40) & $2.38 \pm 08^{b}$ & $20^{\bullet} 20.8^{\prime}$ & $-98^{\bullet} 38.8^{\prime}$ & $10 / 10$ & 333 & 39.2 & 119.9 & 4.4 \\
\hline
\end{tabular}

Sites: referenєe sample from Cantagrel and Robin (1979). Ages: Q, Quaternary; Q(B), Quaternary (Brunhes); Q(M), Quaternary (Matuyama); P, Plioene; (G.C.), Geological correlation; radiometric data. Lat/Long, rock site cordinates; Dec,Inc, delination and inclination of characteristic magnetization; $k, \alpha_{95}$, confidence parameter and $95 \%$ cone of confidence for Fischer statistics; G.C.A. mad, Great Circle Analysis and maximum angular deviation; $n / N$, number of samples included in calcu lation of the mean/collected.

${ }^{a}$ Rejected sites.

- Cantagrel and Robin (1979)

${ }^{\circ}$ Mooser and Soto (1980)

d Osete et al. (2000).

and the northern Sierra Nevada. From the northern flanks of Sierra Nevada (as far as the highway linking Mexico City and Puebla), the Sierra de Río Frío continues northwards towards Pachuca.

\section{Palaeomagnetic sampling and results}

To document the regional pattern of tectonic deformation of the eastern sector of the TMVB, the sampling strategy was designed to constrain, in space and time, the observed rotations. From the western Mexico Basin to the lowlands of the Gulf of Mexico (Fig. 2), 39 volcanic sites with good age control (Table 2.) were sampled. The age of investigated rocks ranges between Miocene
(17 Ma) and Quaternary (Brunhes). They have been supposed to be in the palaeohorizontal, because the lacks of reference sedimentary layers to apply any structural correction due to block tilting.

In the Altiplano area, 18 volcanic sites were sampled, dated by Cantagrel and Robin (1979) excepting five sites that were geologically correlated with their radiometric data. Seven sites are representatives of the Late Miocene andesitic volcanic event (Sierra de Pachuca, correlated with the Zimapán volcanics of $9 \mathrm{Ma}$, and the slightly faulted volcanics dated near Teziutlan of 7.7 Ma). Thirteen sites, between 8.0 and 4.1 Ma in age, were also sampled in the alkaline basaltic lavas outcropping in the fault zone of the Altiplano border. 

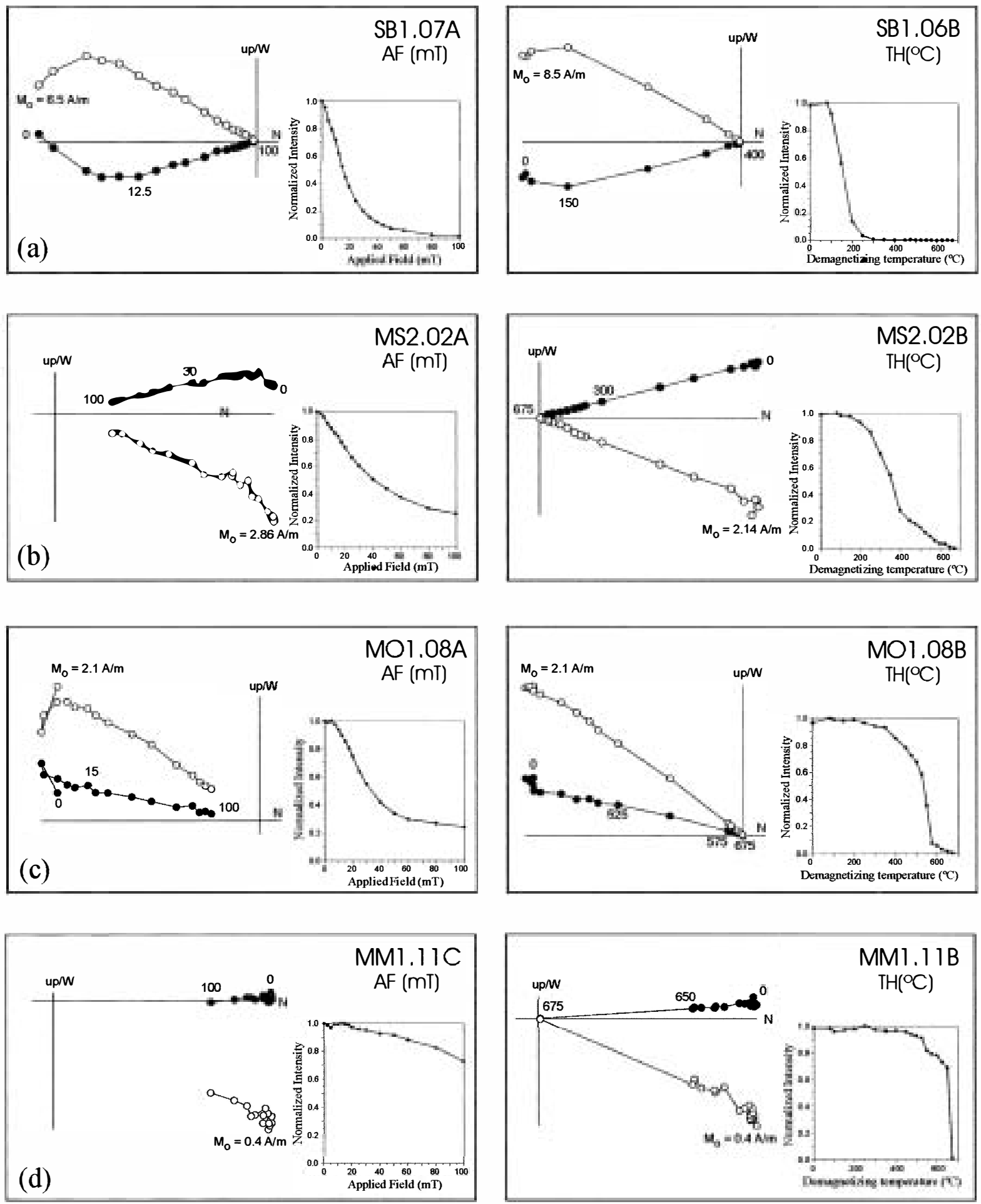
In the Palma Sola massif, four sites were sampled, dated between 17.6 and $3.0 \mathrm{Ma}$. (Cantagrel and Robin, 1979). These include two alkali basalts, a microdiorite and a dacitic dome (also dated by Mooser and Soto, 1980) that is considered to be the last episode of the apparently younger southwards migration of the Late Miocene andesitic phase (Cantagrel and Robin, 1979 ).

A total of 17 volcanic sites, of Quaternary age, was also sampled in the southeastern margin of the Mexico Basin: 12 sites from the Sierra Nevada (most of Brunhes age) and five from the southern Sierra de Río Frío (Table 2).

In addition, results obtained by Osete et al. (2000) in 20 Pliocene and four Quaternary sites from volcanic rocks of the Sierra de las Cruces (western margin of Mexico Basin) have been selected and considered in our tectonic interpretation (Table 2 and Fig. 2). Those sites with intermediate directions or few samples in the calculation of the mean $(N<7)$, were not included.

Palaeomagnetic analyses were carried out on 430 samples from 39 sites, at the palaeomagnetic laboratory of Complutense University of Madrid. The initial susceptibilities ranged from $4.1 \times 10^{-4}$ to $4.3 \times 10^{-2}$ (SI). Measurements of remanence were performed with Molspin and JR5 magnetometers, and susceptibilities with both a Minisep and a KLY-3 kappameter. For a pilot thermal and alternating-field (AF) demagnetization study (using TSD-1 and GSD-5 Schonsted demagnetizers), at least two samples were selected from each site. The following steps were used for the thermally demagnetized pilot samples: steps of $50^{\circ} \mathrm{C}$ from room temperature up to $450^{\circ} \mathrm{C}$ and then steps of $25^{\circ} \mathrm{C}$ up to $7^{\circ} 0^{\circ} \mathrm{C}$. Susceptibility was monitored after each heating to control possible thermally induced mineralogical changes. For pilot AF studies, steps of $2.5 \mathrm{mT}$ (up to $20 \mathrm{mT}$ ), $5 \mathrm{mT}$ (between 20 and $40 \mathrm{mT}$ ) and $10 \mathrm{mT}$ (up to $100 \mathrm{mT}$ ) were used.
The sites are divided into two groups according to their magnetic behavior: (1) sites that showed only one stable magnetic component; and (2) samples with two overlapping magnetic components.

Most sites belonged to the first group (23 of 39 investigated) in which the initial NRM intensities ranged from 0.01 to $13.3 \mathrm{~A} \mathrm{~m}^{-1}$, initial NRM directions were generally well grouped, and the stable directional component could be isolated both during $\mathrm{AF}$ and thermal demagnetization. Most samples had only one magnetic phase with low coercivity (median destructive fields between 10 and $20 \mathrm{mT}$ ) and maximum unblocking temperatures between $350^{\circ} \mathrm{C}$ and $550-575^{\circ} \mathrm{C}$ (Fig $3 \mathrm{a}$ ). This suggests the presence of some fined-grained spinels, and titanomagnetite as the magnetic carrier of the magnetization. However, some sites had a second magnetic phase of higher coercivity and high unblocking temperature (up to $675^{\circ}$ ), probably carried by low-Ti titanohaematites, although slightly maghemitized low-Ti titanomagnetite could also be the carrier of this magnetization (Ozdemir, 1990). Where both low- and high-coercivity phases were present, both magnetic components had similar directions (Fig. 3b-d). After analyses of the pilot specimens the remaining samples were mostly demagnetized by the $\mathrm{AF}$ procedure, in five to ten steps between 20 and $100 \mathrm{mT}$, according to their magnetic properties. Systematic thermal demagnetization was conducted in the same way, between $400-515^{\circ}$ and $650-675^{\circ} \mathrm{C}$, on samples from those sites where a component of high coercivity was observed (Fig. 3d). In both techniques, Principal Component Analysis (PCA, Kirschvink, 1980) was used to isolate the characteristic directions of remanence (ChRM). Two sites of this group, in the Palma Sola and Sierra Nevada regions (PS3 and SM9, see Table 2), were discarded as they were characterized by a high degree of hydrother-

\footnotetext{
Fig. 3. Vector demagnetization and norma lized intensity (inset) plots of Plioene (a, b) and Miocene (c, $\boldsymbol{d}$ ) sites from the Altiplano area with only one directional stab le component. Left/right diagrams correspond to the AF/thernnal demagnetizations, and solid/open circles to the projections onto the horizontal/vertical plane. Sites of reversed (a, c) and nonnal (b, d) polarity, with samples exhibiting only one stable magnetic phase (a) or two magnetic phases with a similar direction (b-d), are shown.
} 

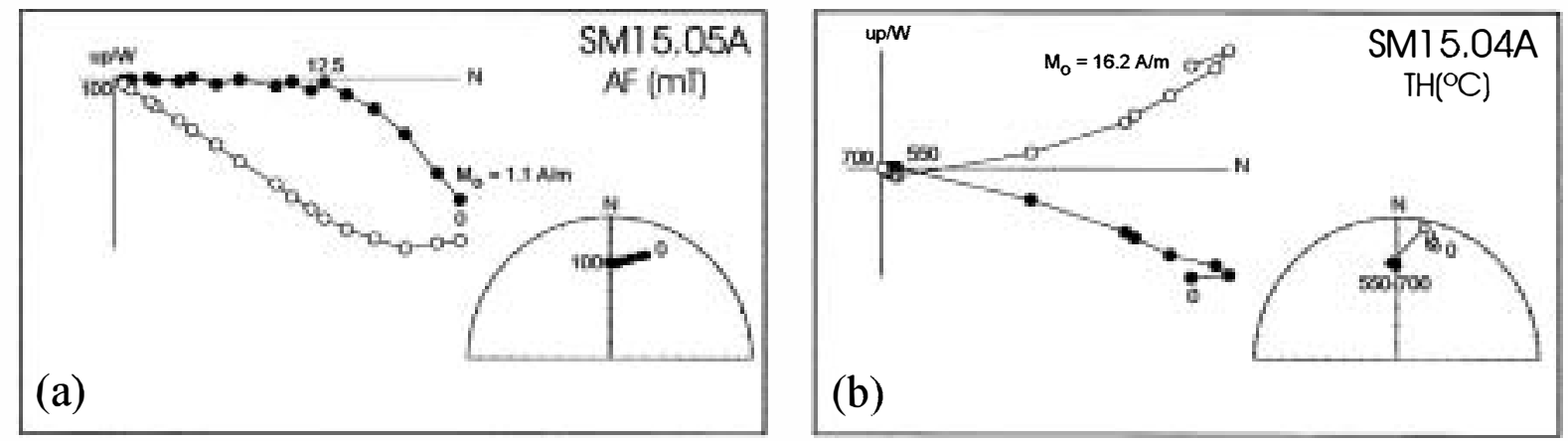

Fig. 4. Vector and equal-area projection plots, during AF (a) and thermal (b) demagnetization, of a Sierra Nevada Quaternary site showing that some samples are highly affected by a secondary IRM. Note the scatter in both NRM intensity values and directions.

mal alteration and an intermediate direction, respectively.

The second group of sites comprised 16 sites which all showed a first, very strong component of low coercivity (median destructive fields between 5 and $27 \mathrm{mT}$ ) and high scatter in both initial NRM directions and intensities (up to $135 \mathrm{~A} \mathrm{~m}^{-1}$ ). Stepwise demagnetization showed the presence of a second magnetic overlapping component. In sites where the component of lower coercivity and lower unblocking temperature exhibited anomalous high intensities, we interpreted an isothermal remanent magnetization (IRM), produced by lightning strikes. One site from Sierra de Río Frío and three more from Sierra Nevada regions (SM2, SM6, SM10, SM12, see Table 2), were eliminated since both demagnetization techniques were ineffective in reducing the high dispersion of their initial NRM directions or isolating any consistent ChRM direction. We interpreted the magnetizations as a total IRM overprint of their unique, low-coercivity magnetic phase. In some cases, the IRM component affected different samples by different amounts, and a stable direction, considered to be the Characteristic remanent magnetization, could be isolated by PCA during the AF demagnetization (Fig. 4a). This IRM overprint did not affect their higher unblocking temperature phase (Fig. 4b). Finally, in six sites with high scatter in the values of the NRM intensities (in two of them showing initial NRM intensities not too high, presumably due to hydrothermal alteration), two components were also observed (Fig. 5). The coercivity spectra did not completely overlap, unlike their unblocking temperature spectra. AF demagnetization removed both components. Directions of the component associated with the lower coercivity phase showed high dispersion. Therefore, we conclude that the ChRM is associated with the higher coercivity phase and can be calculated by Great Circle Analysis (Halls, 1976; McFadden and McElhinny, 1988) after detailed AF demagnetization (about 10 steps were considered). Although PCA was also used for some of these samples, the convergence of remagnetization circles provides the best statistical grouping. We discarded one mean direction from the Teziutlan volcanics (MR1, see Table 2) because we interpret the direction as an intermediate one.

\section{Discussion and conclusions}

In summary, 32 of the 39 sampled sites are considered useful for tectonic interpretation (Table 2). These can be combined with the 24 sites investigated by Osete et al. (2000) from Sierra de Las Cruces (Table 2), at the western limit of the Mexico basin (intermediate site-mean directions or sites with less than seven samples in the calculation of the mean, have not been included). To investigate the existence of local block rotations, the mean directions and palaeomagnetic poles from the eastern part of central Mexico were compared with the geographical pole (Quaternary sites) and with Miocene and Pliocene North 
Table 3

Summary of mean directions and VGPs

(a) Reference poles and expected directions

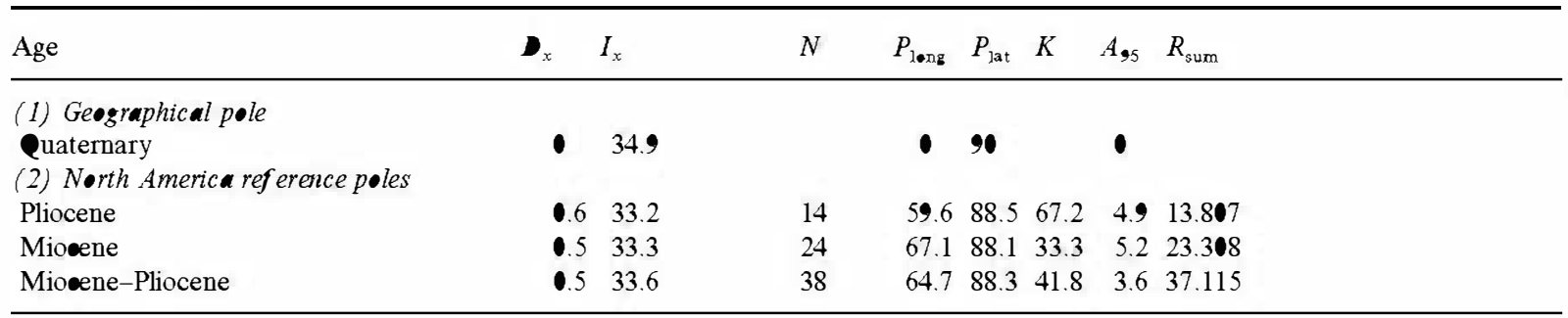

(b) Mean directions according to geographical distribution

\begin{tabular}{lrllllllllllll}
\hline Area $\left(N_{i}\right.$, age $)$ & $N$ & Dec & Inc & $k$ & $\alpha_{95}$ & $r_{\text {sum }}$ & $P_{\text {løng }}$ & $P_{\text {lat }}$ & $K$ & $A, 5$ & $R_{\text {sum }}$ & $R \pm \Delta R$ & $F \pm \Delta F$ \\
\hline S. Nevada-S. Rio Frío (Q) & 12 & 358.5 & 29.7 & 49.1 & 6.3 & 11.776 & $\mathbf{9 6 . 8}$ & 86.8 & 45.8 & 6.5 & 11.760 & $-1.5 \pm 58$ & $52 \pm 5$ \\
S. De Las Cruøes (20 P, 4 Q) & 24 & 351.7 & 30.3 & 32.5 & 5.3 & 23.293 & 159.8 & 81.0 & 47.9 & 4.3 & 23.520 & $-89 \pm 6.4$ & $29 \pm 7.4$ \\
Altiplano (10 M, 7 P) & 17 & 350.0 & 38.4 & 21.0 & 8.0 & 16.239 & 188.1 & 80.5 & 20.3 & 8.1 & 16.213 & $-105 \pm 87$ & $-48 \pm 78$ \\
Palma Sola (2 M, 1 P) & 3 & 352.2 & 37.6 & 26.8 & 24.3 & 2.925 & 190.7 & 82.1 & 47.9 & 18.0 & 2.958 & $-8.4 \pm 252$ & $-46 \pm 199$ \\
\hline
\end{tabular}

(c) Mean directions according to age

\begin{tabular}{|c|c|c|c|c|c|c|c|c|c|c|c|c|c|}
\hline $\operatorname{Age}\left(N_{\mathrm{i}}\right.$, area $)$ & $N$ & Dec & Inc & $k$ & $\alpha_{95}$ & $r_{\text {sum }}$ & $P_{\text {leng }}$ & $P_{\text {lat }}$ & $K$ & $A_{95}$ & $R_{\text {sum }}$ & $R \pm \Delta R$ & $F \pm \Delta F$ \\
\hline Qnaternary (4 SC, 4 SRF, $8 \mathrm{SN}$ ) & 16 & 357.6 & 32.2 & 42.1 & 5.8 & 15.643 & 137.8 & 87.7 & 46.0 & 5.5 & 15.674 & $-2.4 \pm 55$ & $27 \pm 46$ \\
\hline Pliocene (2 SC, 7 ALT, 1 PS) & 28 & 350.8 & 29.2 & 41.8 & 4.3 & 27.354 & 154.1 & 79.9 & 58.4 & 3.6 & 27.538 & $-9 \pm 57$ & $40 \pm 70$ \\
\hline Miocene (10 ALT, 2 PS) & 12 & 350.8 & 43.2 & 16.8 & 10.9 & 11.345 & 211.1 & 79.4 & 16.0 & 11.2 & 11.312 & $-7 \pm 128$ & $-99 \pm 10.8$ \\
\hline $\begin{array}{l}\text { Miocene-P liocene } \\
\text { (17 ALT, } 3 \text { PS, } 2 \text { SC) }\end{array}$ & 40 & 350.8 & 33.2 & 25.4 & 4.6 & 38.463 & 170.4 & 80.8 & 30.8 & 4.1 & 38.732 & $-97 \pm 5.3$ & $0.4 \pm 5.8$ \\
\hline $\begin{array}{l}\text { Late Miocene-P liocene } \\
\text { (17 ALT, } 20 \mathrm{SC} \text {, withont PS) }\end{array}$ & 37 & 350.7 & 33.2 & 24.8 & 4.8 & 35.547 & 169.0 & 80.6 & 29.5 & 4.4 & 35.779 & $-98 \pm 55$ & $6 \pm 59$ \\
\hline
\end{tabular}

Area: SC, Sierra de Las Cruces; SN, Sierra Nevada; SRF, Sierra de Río Frío; ALT, Altiplano; PS, Palma Sola. Age: Q, Quaternary; P, Pliocene; M, Mioene. $N\left(N_{\mathrm{i}}\right)$, number of sites; $\boldsymbol{D}_{x}, I_{x}$, expected direction for the studied area; $P_{\text {leng }} / P_{\text {lat }}$, palaeomagnetic pole coordinates; Dec, Inc, observed mean direction; $k, \alpha_{95}, r_{\text {sum }}\left(K, A_{95}, R_{\text {SUM }}\right)$ : confidence parameter, $95 \%$ cone of confidence and length of the resultant vector for Fisher statistics (Fisher, 1953). $R \pm \Delta R / F \pm \Delta F$, rotation/flattening parameters with their confidence limits (Beck, 1981; Demarest, 1983)

American reference poles (Table 3). To calculate these mean palaeomagnetic poles for North America, mean virtual geomagnetic poles (VGPs) have been extracted from the IAGA Global Palaeomagnetic Database (McElhinny and Lock, 1996), updated at the end of 1997. Directions with statistical parameters $k<20$ and $\alpha_{95}>15^{\circ}$ were excluded, as well as palaeomagnetic results from areas that do not represent to stable America (mainland Mexico and Baja California peninsula). In addition, the amounts of vertical-axis rotation
$(R)$ and flattening of inclination $(\boldsymbol{F})$, have been evaluated (Beck, 1980), with their confidence limits (Demarest, 1983).

Directions of the ChRMs from the eastern part of central Mexico, grouped in different ways to investigate possible directional changes associated with their: (1) age; and (2) location and magmatic composition (Table 3 ):

(1) The mean directions for rocks older and younger than $2 \mathrm{Ma}$ are significantly different. The declination of the oldest is rotated some $1^{\circ}$ 

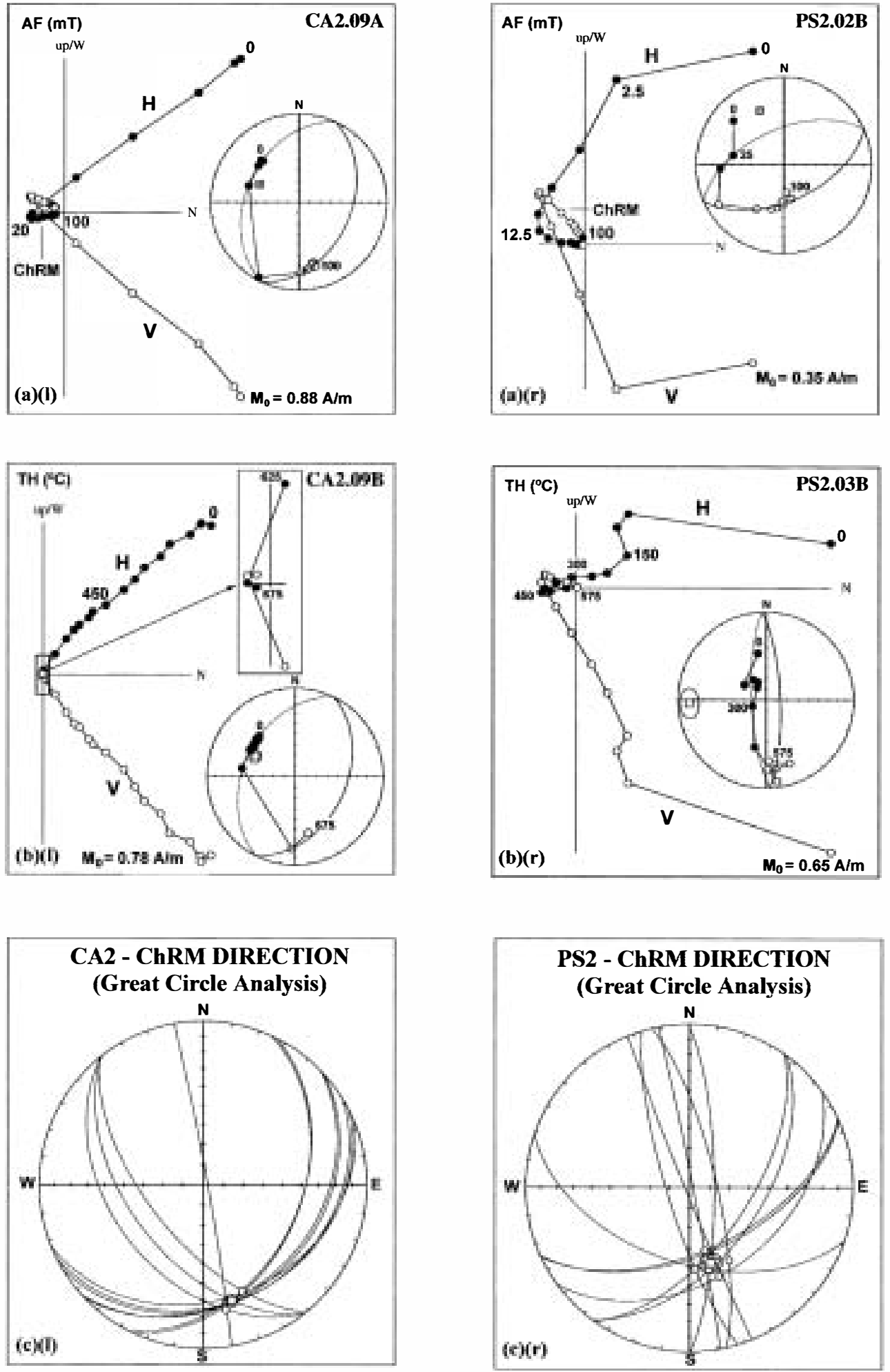
Table 4

Reversal test results

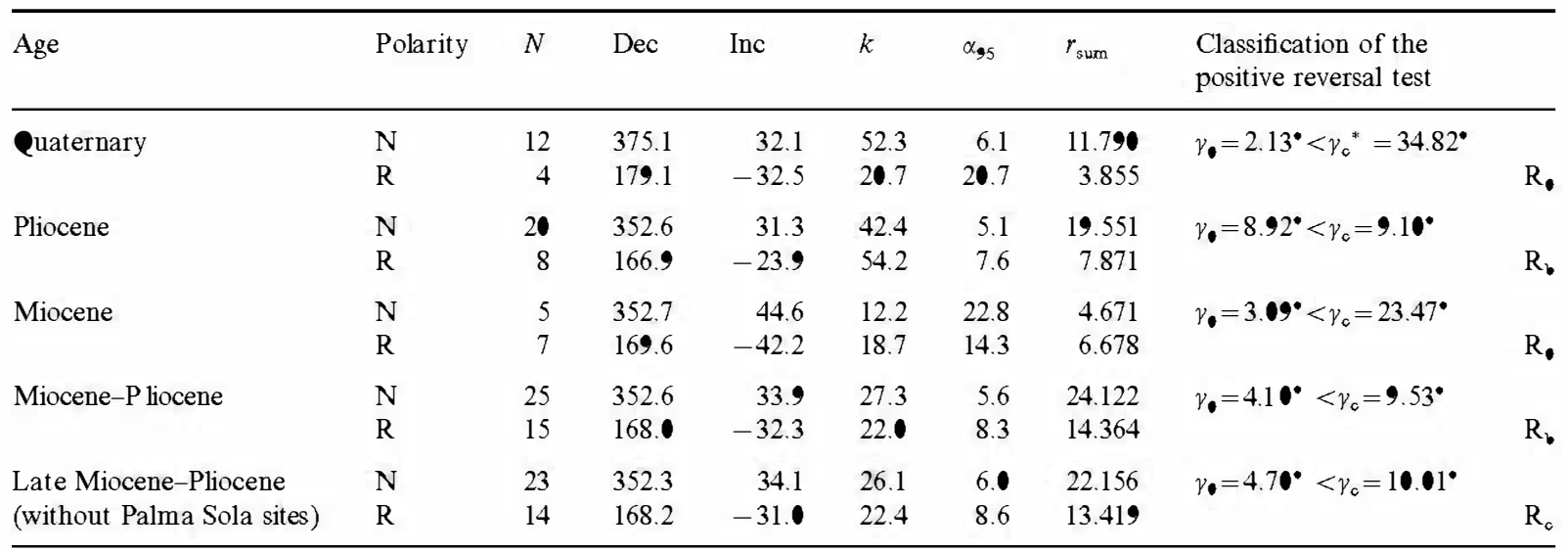

Polarity: N/R: nonna 1/reverse; $N$, number of sites; Dec/Inc, mean direction; $k, \alpha_{95}, r_{\text {sum }}$, confidence parameter, $95 \%$ cone of confidence and length of the resultant vector for Fisher statistics (Fisher, 1953). Reversal tests: $\gamma_{0}$, angle between the two mean directions; $\gamma_{c}$, critical angle (" using simulation without the assumption of a common precision (McFadden, 1990); $R_{\mathbf{f}}, \mathrm{R}_{\mathrm{b}}, \mathrm{R}_{\mathrm{c}}$, positive reversal test with classifications 'indeterminate', 'B' and 'C', respectively (McFadden and McElhinny, 1990).

counterclockwise with respect to the youngest (Table 3). Miocene, Pliocene and Quaternary directions pass the reversal test of McFadden and McElhinny (1990) at the $\mathbf{9 5 \%}$ confidence level (Table 4). This antipodal character of the normal and reversed directions indicates that any possible overprint has been sufficiently removed and other causes of dispersion have been averaged. To test if the data sets provide the time averaging of Secular Variation, their observed site-mean VGPs angular dispersion have been compared with those predicted from Merril and McElhinny (1983). Pliocene and Quaternary VGPs angular dispersions are consistent with the predicted dispersion of $13-14^{\bullet}$ for the palaeolatitude of the studied area. However, the Miocene one is some $7^{\bullet}$ greater. We interpret this as being due to a random tectonic disturbance that has been averaged as the positive reversal test indicates. A statistical comparison can be carried out between the Pliocene and Quaternary sites because both populations have common precision parameters. Result of the McFadden and McElhinny test (1990) is negative $\left(\gamma_{\bullet}=7.95^{\circ}\right.$ and $\left.\gamma_{c}=6.19^{\circ}\right)$. Therefore, both directions are statistically different at the $\mathbf{9 5 \%}$ confidence level. No rotational differences have been observed between Miocene and Pliocene rocks (Table 3), although, in this case, statistical tests can not be performed because precision parameters of Miocene directions are not comparable with those of Pliocene and/or Quaternary times.

(2) The mean direction from Sierra de Las Cruces (mostly Pliocene) is similar to that calculated for the Altiplano Area (Miocene and Pliocene). Both are deviated westwards respect to the Sierra Nevada and Sierra de Río Frío (Quaternary). Although the deviation is small, it seems that is related to the ages of the investigated rocks and not with their geographical location (Table 3 ). This suggests that the eastern TMVB can be considered a unique tectonic domain (i.e. not different rotational blocks can be observed). The results from the three Miocene-Pliocene sites from Palma Sola massif cannot be considered statistically representative because of the low number of sites available, but their direction is similar to the Miocene-

Fig. 5. Vector and equal-area projection plots, during the AF (a) and thernal (b) demagnetization, of two Miocene sites from the Altiplano area (left) and the Palma Sola Massif (right), representative of those that showed the presence of two over lapping magnetic components. Mean-site directions are accurately calculated by great-circle analysis (c). 
Pliocene sites from the eastern TMVB. As discussed above (see Section 2), at least the Miocene sites might belong to a different volcanic province. For these reasons, Palma Sola sites will not be consid- ered in the representative mean direction of the TMVB. Nevertheless, the TMVB mean direction does not change if the three Palma Sola sites are included (Table 3).
a) ChRM and mean
b) Site - Mean VGPs directions
c) Mean palaeomagnetic \& Reference poles
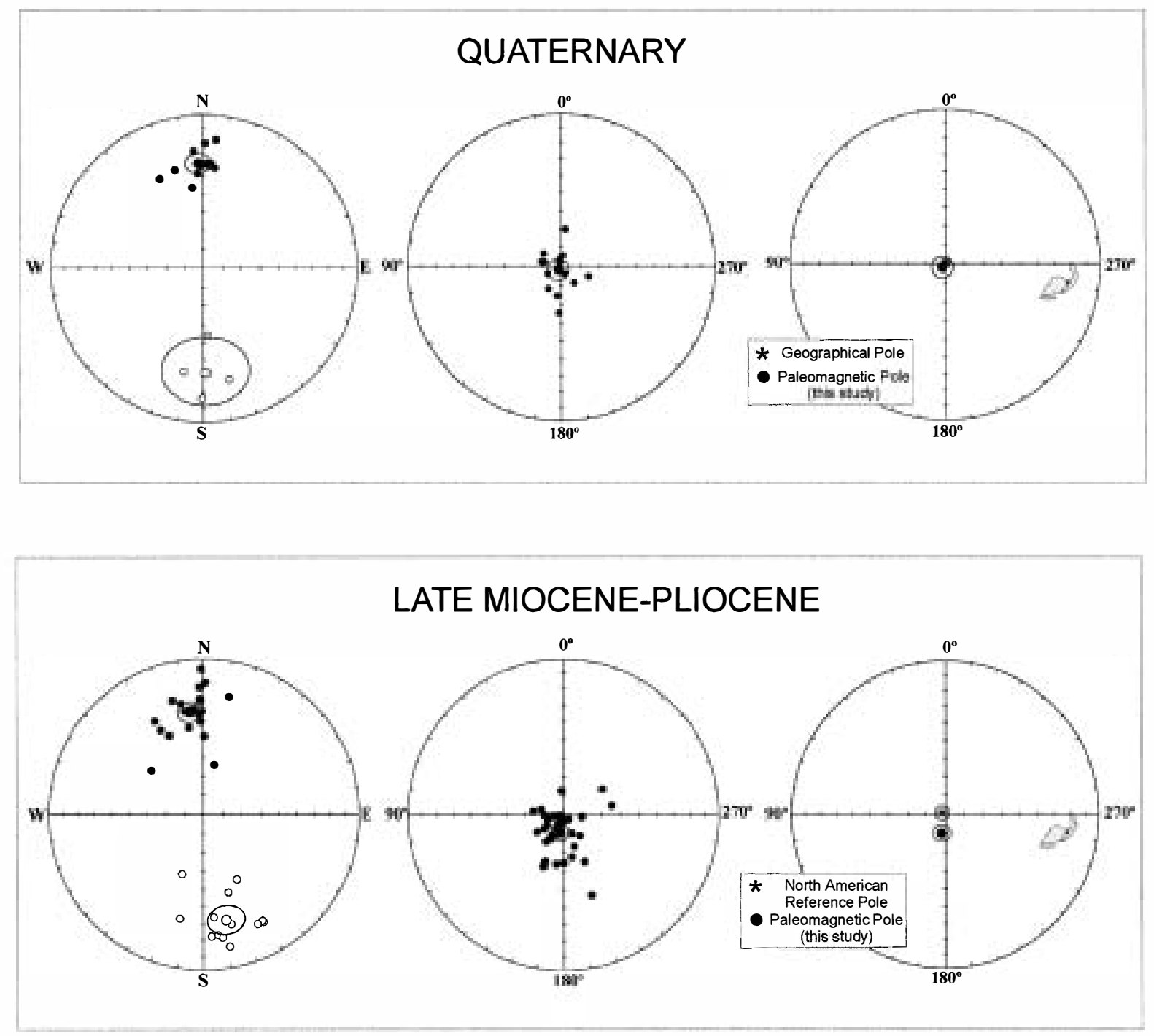

Fig. 6. Equal-area projections showing: (a) normal (solid)/reversed (open) site-mean characteristic (ChRM) directions and normal/reversed) mean directions for the Quaternary and Late Miocene-Pliocene investigated sites (Palma Sola sites are not included). (b) Corresponding site-mean VGPs and mean poles. (c) Quaternary and Late Miocene-Pliocene mean palaeomagnetic poles for eastern TMVB and reference poles. 95\% confidence limits are also shown. Late Miocene-Pliocene palaeomagnetic pole is rotated some $10^{\circ}$ counterclockwise (see the Mexico sketch and the TMVB location) with respect to both the geographical pole and the Miocene-Pliocene reference pole for North America. 
Consequently, two groups can be differentiated according to the palaeomagnetic data. These are: (1) The Quaternary volcanic outcrops of Sierra Nevada, Sierra de Rio Frio and Sierra de las Cruces; and (2) the late Miocene-Pliocene (back to $9 \mathrm{Ma}$ ) volcanic outcrops extending from the western Mexico basin (Sierra de las Cruces) to the border of the Altiplano. Directions of both groups fail the McFadden and McElhinny (1990) statistical test $\left(\gamma_{\bullet}=7.40\right.$ and $\left.\gamma_{c}=7.32\right)$. This indicates that differences in directions between these groups are significant at the $\mathbf{9 5 \%}$ confidence level.

The mean directions and palaeomagnetic poles obtained for the Quaternary and late MiocenePliocene eastern TMVB sites were compared with the geographic and the Miocene-Pliocene North American reference poles, respectively (Table 3 and Fig. 6). Both observed and reference poles coincide for the Quaternary time but are statistically different for the Miocene-Pliocene time, inferring that a very small counterclockwise vertical

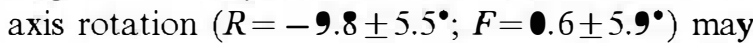
have taken place in this segment of the TMVB between late Pliocene and Quaternary time.

Results from the late Miocene-Pliocene eastern TMVB seem to be more consistent than the two palaeopoles reported for the Atotonilco el Grande sequence $\left(82^{\circ} \mathrm{N}, 167^{\circ} 30 \mathrm{~W}\right)$ and the Tlanchinol volcanic rocks $\left(81^{\circ} 30 \mathrm{~N}, 116^{\circ} \mathrm{W}\right)$, in the Altiplano area (Robin and Bobier, 1975), that agree within confidence limits.

Summarizing, the new results reported here do not support the notion that large rotations occurred in the TMVB in recent times [e.g. entries (4) and (13-E1), see Table 1]. No large rotations have been observed in the youngest volcanic rocks of the eastern TMVB. The few results from Palma Sola massif do not support the existence of large rotations in this area in post late Miocene time. The origin of these discrepancies can be related with the age-control of the volcanic outcrops, the Secular Variation, the incomplete isolation of the ChRM and/or some other systematic mistakes. In this study well-dated rocks have been sampled, and the reversal and other statistical test have been applied. Not statistical tests were performed in the other studies, then, it is not sure that the Secular Variation was properly averaged and the ChRM well isolated. In addition, if the present declination in Mexico (ca. $\mathbf{7}^{\mathbf{E}} \mathrm{E}$ ) is not properly corrected, it could produce erroneous apparent counterclockwise rotations of ca. $14^{\bullet}$. Therefore counterclockwise rotations of about this value in Quaternary rocks are very suspicious and should be revised.

In addition, palaeomagnetic results presented here are consistent with recent geological studies that indicate that the main stress regime (Vegas et al., 1998) in the eastern TMVB, Altiplano border and coastal plains, is extensional. Comparisons of our new results with the large counterclockwise rotations summarized by Urrutia-Fucugauchi and Böhnel (1988) from Cretaceous to Miocene rocks from the eastern TMVB, indicate that most of rotation probably took place before late Miocene time. Our palaeomagnetic results seem to support the Oligocene to Recent tectonic evolution phases, proposed by Ferrari et al. (1994), that affected the TMVB. They considered that the TMVB began at ca. $16 \mathrm{Ma}$ and that its tectonic evolution comprised a Middle Miocene phase of transcurrent faulting followed by a transtensional to extensional phase between the Late Miocene time and present.

No significant rotations have been observed between late Miocene and late Pliocene time, only a small amount of rotation occurred between late Pliocene and Quaternary time. In conclusion, these new palaeomagnetic data do not support the strike-slip megashear models that produces large, vertical-axis block rotations, but support the idea that the eastern TMVB, since late Miocene time, has been a zone of extension with a little, leftlateral shear component.

\section{Acknowledgements}

The authors appreciate very much the help of Peter Keller and Martin Espinosa during fieldwork. They are especially grateful to the reviewers Claudia J. Lewis and Xixi Zhao for their useful comments and suggestions. The entire project was supported by the European Union (project: CI-CT94-0114). 


\section{References}

Anderson, T.H., Schmidt, V.A., 1983. The evolution of Midd le America and the Gulf of Mexico-Caribbean Sea region during Mesozoic times. Geol. Soc. Am. Bull. 94, 941-966.

Bandy, W.L., Mortera-Gutiérrez, C., Urrutia-Fucugauchi, J., Hilde, T.W.C., 1995. The subducted Rivera-Cocos plate boundary: where is it, what is it, and what is its relationship to the Colima Rift? Geophys. Res. Lett. 22, 3075-3078.

Beck Jr, M.E., 1980. Paleomagnetic record of plate-margin tectonic processes along the western edge of North America J. Geophys. Res. 85, 7115-7131.

Böhnel, H., 1985. Paläomagnetische Untersuchungen an Jurassichen bis Quartären Gesteinen aus Zentral- und Süd Mexiko. Doktor Dissertation, Thesis Westfälischen Wihelms Universität Münster

Böhne 1, H., Negendank, J.F.W., 1981. Preliminary results of palaeomagnetic measurements of Tertiary-Quaternary igneous rocks from the eastern part of the Trans-Mexican Volcanic Belt. Geofis. Int. 20 (3), 235-248

Burbach, G.V., Froh lich, C., Pennington, W.D., Matumoto, T., 1984. Seismicity and tectonics of the subducted Cocos plate. J. Geophys. Res. 89, 7719-7735.

Cantagre1, J.M., Robin, C., 1979. K-Ar dating on Eastern Mexican volcanic rocks - relations between the andesitic and the alkaline Provinees. J. Vo lcanol. Geotherm. Res. 5, 99-114.

Carta geológica de la República Mexicana 1992. Escala 1:2 100 000. Consejo de Recursos Minera les e Instituto de Geología, México

Dañobeitia, J.J., Córdoba, D., Delgado-Argote;, L.A., Michaud, F., Barto lomé, R., Farran, M., Carbonell, R., Nuñez-Cornu, F., CORT ES-P96 WG 1997. Expedition Gathers New Data on Crust Beneath Mexican West Coast. EOS, Trans. Arn. Geophys. Union 78, 49

De Cserna, Z., 1970. Mesozoic sedimentation, magmatic activity and defornation in northern Mexico. In: The Geologic Framework of the Chihuahua Tetonic Belt. West Texas Geol. Soc, Texas, USA, pp. 99-117.

De Cserna, Z., 1976. Mexico-Geotectonics and mineral deposits. In: Woodward, L.E.N., Northrop, S.A. (Eds.), Tectonic and Minerals of Southwestern North America, New Mexico Geo1. Soc. Spec. Pub1. 6, 18-25

Delgado-Granados, H., Urrutia-Fucugacuhi, J., Hasenaka, T., Ban, M., 1995. Southwestward volcanic migration in the western Trans-Mexican Vo lcanic Belt during the last $2 \mathrm{Ma}$. Geof. Int. 34 (3), 341-352

Demant, A., 1978. Características del Eje Neovo lcánico Transmexicano y sus problemas de interpretación. Revista Inst. Geo1. U.N.A.M. 2, 172-187

Demant, A., Robin, C., 1975. Las fases del vulcanismo en Mexico, una sintesis en relación con la evolución geodinámica desde el Cretácico. Rev. Inst. Geol., U.N.A.M. 75, 70-82.

Demarest, H.H., 1983. Error analysis for the determination of tectonic rotation from palaeomagnetic data. J. Geophys. Res. 88, 4321-4328.
Drumond, K.J., 1981. Plate Tectonic Map of the Circum-Pacific Region Northest quadrant sca le 1:10 000 000. Am. Assoc. Petro 1. Geol.

Ferrari, L., Garduño, V.H., Pasquaré, G., Tiba ldi, A., 1994 Vo lcanic and tectonic evolution of central México: Oligocene to present. Geofis. Int. 33 (1), 91-105.

Fisher, R.A., 1953. Dispersion on a sphere. Proc. R. Soc. London A 217, 295-305.

Halls, H.C., 1976. A least-squares method to find a remanence direction from converging remagnetization circles. Geophys J. R. Astron. Soc. 45, 297-304.

Herrero Bervera, E., Urrutia-Fucugauchi, J , Martin-del Pozzo, A.L., Böhnel, H., Guerrero, J.C., 1986. Normal amplitude Brunhes paleosecu lar variation at low latitudes: a paleomagnetic record from Trans-Mexican Volcanic Belt. Geophys. Res. Lett. 13, 1442-1445

Johnson, C.A., Harrison, C.G.A., 1989. Tectonics and volcanism in central Mexico: a Landsat thematic mapper perspective. Remote Sens. Environ. 28, 273-286.

Johnson, C.A., Harrison, C.G.A., 1990. Neotectonics in central Mexico. Phys. Earth. Planet. Inter. 64, 187-210

Kirschvink, J.L., 1980. The least-squares line and plane and the analysis of paleomagnetic data. Geophys. J. R. Astron. Soc. $62,699-718$

Lange, R.A., Cannichael, I.S.E., 1991. A potassic volcanic front in Western Mexico: the lamprophyric and related lavas of San Sebastian. Geol. Soc. Am. Bull. 103, 928-940.

Luhr, J.F., Carmichael, I.S.E., 1985. Contemporaneus eruptions of cal-calkaline and alkaline magmas along the volcanic front of the Mexican Volcanic Belt. Geofis. Int. 24, 203-216

Maillo1, J.M., Bandy, W.L., 1994. Palaemagnetism of the Talpa de Allende and Mascota grabens, western Mexico: a preliminary report. Geofis. Int. 33 (1), 153-160

McElhinny, M.W., Lock, J., 1996. IAGA paleomagnetic databases with Acœess. Surv. Geophys. 17, 757-791

McFadden, P.L., 1990. A new fold test for palaeomagnetic studies. Geophys. J. Int. 103, 163-169.

McFadden, P.L., McElhinny, M.W., 1988. The combined analysis of remagnetization circles and direct observations in palaeomagnetism. Earth Planet. Sci. Lett. 87, 161-172.

McFadden, P.L., McElhinny, M.W., 1990. Classification of the reversal test in palaeomagnetism. Geophys. J. Int. 103, 725-729.

Merril, R.T., McElhinny, M.W., 1983. The Earth's Magnetic Field: its History, Origin and Planetary Perspective. Academic Press, London.

Mo lnar, P., Sykes, L.R., 1969. Tectonics of the Caribbean and Middle American regions from focal mechanisms and seismicity. Geol. Soc. Am. Bull. 80, 1639-1684.

Mooser, F., 1972. The Mexican volcanic belt: structure and tectonics. Geofis. Int. 12, 55-70.

Mooser, F., Soto, S., 1980. In: Geology of Laguna Verde III Comisión Federal de Electricidad, México, D.F

Mooser, F., Nairn, A.E.M., Negendank, J.F.W., 1974. Palaeomagnetic investigations of the Tertiary and Quaternary igne- 
ous rocks: VIII. A palaeomagnetic and petrologic study of volcanics of Valley of Mexico. Geol. Rundsch. 63, 451-483.

Mora-Alvarez, G., Caballero, C., Urrutia-Fucugauchi, J., Uchiumi, Sh., 1991. Southward migration of volcanic activity in the Sierra de Las Cruces, basin of Mexico? A preliminary $\mathrm{K}-\mathrm{Ar}$ dating and palaeomagnetic study. Geofis. Int. 30 (2), 61-70

Negendank, J.F.W., Emmermann, R., Krawczyck, R., Mooser, F., Tobschall, H., Werle, D., 1985. Geological and Geochemical investigation on the eastern Trans-Mexican Volcanic Belt. Geofis. Int. 24 (4), 477-575

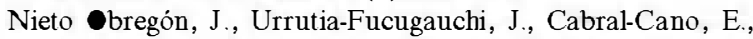
Guzman de la Campa, A., 1992. Listric faulting and continental rifting in western Mexico - a paleomagnetic and structural study. Tectonophysics 208, 365-376.

Nixon, G.T., 1982. The relationship between Quaternary volcanism in central México and the seismicity and the structure of subducted oeanic lithosphere. Geol. Soc. Am. Bull. 93, 514-523.

Nixon, G.T., 1989. The Geo logy of Iztaccíhuat 1 Vo lcano and Adjaøent Areas of the Sierra Nevada and Valley of Mexico. Geol. Soc. Am. Spec. Pap. 219

Nixon, G.T., Demant, A., Amstrong, R.L., Harakal, J.E., 1987. $\mathrm{K}-\mathrm{Ar}$ and geologic data bearing on the age and evolution of the Trans-Mexican Volcanic Belt. Geofis. Int. 26 (1), 109-158

-sete, M.L., Ruiz-Martinez, V.C., Caballero, C., Ga lindo, C., Urrutia-Fucugauchi, J., Tarling, D.H., 2000. Southward migration of continental activity in the Sierra de las Cruøes, Mexico: Palaeomagnetic and radiometric evidence. Tectonophysics 319 .

-zdemir, ๑., 1990. High-temperature hysteresis and thernoremanenee of single-domain maghemite. Phys. Earth. Planet. Inter. $65,125-136$

Pardo, M., Suárez, G., 1995. Shape of the subducted River and Cocos plates in southern México: seismic and tectonic implications. J. Geophys. Res. 100, B7, 12357-12373.

Pasquaré, G., Ferrari, L., Garduño, V.H., Tiba Wli, A., Vezzo li, L., 1991. Geology of the central sector of the Mexican Volcanic Belt, States of Guanajuato and Michoacán. Geol. Soc. Am. Map and Chart series $\mathrm{MCH} 072$.

Robin, C., 1976. Présence simultanée de magmatismes de significations tectoniques opposées dans lést du Mexique. Bull. Soc. Géol. Fr. 18, 1637-1645.

Robin, C., 1981. Relations Vo lcanologie-Magmatologie-Géodynamique: Application au passage entre volcanismes alca lin et andésitique dans le Sud Mexicain. (Axe transmexicain et Province alcaline Orientale). Ann. Sci. De p'Univ, de Clennont-Ferrand II

Robin, C., Bobier, C., 1975. Las fases del vulcanismo en la region de Tlanchinol (Hidalgo, Mexico) segúu datos paleo- magneticos y geoquimicos. Bol. Inst. Geol. U.N.A.M. 95, 49-85.

Rosas-Elguera, J., Urrutia-Fucugauchi, J., 1992. Magnetoestratigrafía volcánica de la zona geotérnica Ixtlán de los Hervores-Los Negritos, Michoacán, México: Resultados preliminares. Geofis. Int 31 (4), 431-442.

Shurbet, D.H., Cebull, S.E., 1984. Tectonic interpretation of the Trans-Mexican volcanic belt. Tectonophysics 101, $159-165$.

Soler-Arecha lde, A.M., Urrutia-Fucugauchi, J., 1994. Regional rigid block-rotation, small domains rotations and distributed defornnation within the Acambay graben, central Tranx-Mexican Volcanic Belt: paleomagnetic implications. Geofis. Int. 33 (4), 564-574.

Soler-Arecha lde, A.M., Urrutia-Fucugauchi, J., 2000. Palaeomagnetism of the Acambay graben, central Tranx-Mexican Vo lcanic Belt. Tectonophysics 319

Suárez, G., Singh, S.K., 1986. Tectonic interpretation of the Trans-Mexican Volcanic Belt - discussion. Tectonophysics $127,155-160$

Uribe-Cifuentes, R.M., 1992. Paleomagnetismo y Magnetoestratigrafí a de la zona norte del Campo Volcánico Michoacán-Guanajuato. Tesis de Maestría en Geofísica. UACPyP del CCH. Instituto de Geofísica UNAM.

Urrutia-Fucugauchi, J., 1980. Paleomagnetic studies of Mexican rocks. Ph.D. Thesis, University of Newecast le upon Tyne, UK

Urrutia-Fucugauchi, J., 1981. Paleomagnetism of the Mioene Jantetelco microdiorites and Tepexco volcanic group and inferenøes for block rotations in Central Mexico. Tectonophysics $76,149-168$

Urrutia-Fucugauchi, J., 1983. Preliminary palaeomagnetic study of Lower Tertiary volcanic and rocks from Morelos and Guerrero states. Geofis. Int. 22,87-110

Urrutia-Fucugauchi, J., 1984. On the tectonic evolution of Mexico: paleomagnetic constrains. Am. Geophys. Union, Geodyn. Ser. 12, 29-47.

Urrutia-Fucugauchi, J., Böhnel, H., 1988. Tectonics along the Trans-Mexican volcanic belt according to palaeomagnetic data. Phys. Earth Planet. Inter. 52, 320-329

Urrutia-Fucugauchi, J., Del Castillo, L., 1977. Un modelo del Eje Volcánico Mexicano. Bol. Soc. Geol. Mex. 38, 18-28.

Urrutia-Fucugauchi, J., Pa 1, S., 1977. Paleomagnetic data from Tertiary igneous rocks, northeast Jalisco, Mexico. Earth Planet. Sci. Lett. 36, 202-206.

Vegas, R., Rincón, P.J., de Viœnte, G., 1998. Estado de esfuerzos neotectónicos en el segmento oriental del eje Neovolcánico Transmexicano, borde del Altiplano y llanura costera. Geos 18 (4), 302.

Watkins, N.D., Gunn, B.M., Baksi, A.K., York, D., Ade-Hall, J., 1971. Paleomagnetism, geochemistry and potassiumargum ages of the Rio Grande de Santiago volcanics, Central Mexico. Geol. Soc. Am. Bu 11. 82, 1955-1968. 